\title{
ELISA RESPONSE AND GLIADIN COMPOSITION OF DIFFERENT WHEAT CULTIVARS GROWN IN MULTIPLE HARVEST YEARS
}

\author{
L. HAJAS ${ }^{\mathrm{a}}$, K. A. ScherF ${ }^{\mathrm{b}}$, Zs. BugYI ${ }^{\mathrm{a}}$, K. TÖRÖK ${ }^{\mathrm{a}}$, E. SCHALL ${ }^{\mathrm{a}}$, P. KÖHLER ${ }^{\mathrm{b}}$ and \\ S. ТӧмÖSкÖZа ${ }^{a *}$ \\ aDepartment of Applied Biotechnology and Food Science, Faculty of Chemical Technology and Biotechnology, \\ Budapest University of Technology and Economics, H-1111 Budapest, Szent Gellért tér 4. Hungary

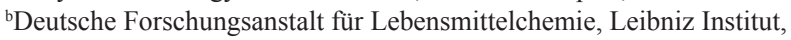 \\ Lise-Meitner-Straße 34, 85354 Freising. Germany
}

(Received: 28 April 2016; accepted: 31 August 2016)

\begin{abstract}
In special dietary products for people intolerant to gluten, gluten content is not supposed to exceed the regulatory thresholds. Enzyme-linked immunosorbent assays (ELISAs) are routinely used to quantitate gluten in these products. They measure gliadin/gluten with high specificity and sensitivity, but they have some limitations. Quantitative and qualitative variability of the target proteins among wheat cultivars is a factor that may cause inaccurate results. One of the aims of this work was to characterize the protein composition of five wheat cultivars grown in multiple harvest years and their blends by reversed-phase high-performance liquid chromatography (RP-HPLC). The gliadin/gluten content of these wheat flours was also analysed with two commercial ELISA kits. The effect of differences in protein profiles between the flours from an individual cultivar and the blend of five cultivars, harvest years, as well as processing procedures (dough forming and baking) on the results of two ELISA kits was investigated and their relative magnitude was determined. Among the factors investigated, the differences between flours had the greatest impact on gliadin recoveries.
\end{abstract}

Keywords: wheat flour, protein composition, gluten-free, gliadin/gluten, incurred matrix, ELISA

The ingestion of food from gluten-containing grains can trigger a number of harmful reactions in susceptible individuals, e.g. celiac disease, wheat allergy, and non-celiac gluten sensitivity. Gluten (especially its prolamin fraction) from wheat, rye, and barley is the precipitating factor for celiac disease (KoEHLER et al., 2016). Patients must eliminate these grains from their diet, because currently this is the only effective strategy to avoid the symptoms (SABATINO et al., 2013). Two thresholds are defined: the terms 'gluten-free' and 'very low gluten' mean that the gluten content in these products is below 20 and $100 \mathrm{mg} \mathrm{kg}^{-1}$, respectively (ComMission of the EuRopean Communities, 2009). Reliable analytical methods are needed to assess the gluten content of these products and to enforce regulations. Currently, immunochemical assays (enzyme-linked immunosorbent assays (ELISAs) and lateral flow devices (LFDs)) are the preferred methods for determining such low amounts of protein. However, gluten quantitation with ELISA is accompanied by numerous problems, because gluten is a complex mixture of heterogeneous proteins with different solubility, composition, and immunoreactivity (Diaz-Amigo \& Popping, 2012, 2013; Scherf et al., 2016).

Most commercial gluten immunoassays are based on determining prolamins, which are soluble in aqueous alcohols (SCHERF \& POMS, 2016). Although the primary structure of prolamins appears to be relatively stable, food processing might induce post-translational

\footnotetext{
* To whom correspondence should be addressed.

Phone: +36-1-463-1419; fax: +36-1-463-3855; e-mail: tomoskozi@mail.bme.hu
}

This is an open-access article distributed under the terms of the Creative Commons Attribution 4.0 License, which permits unrestricted use, distribution, and reproduction in any medium for non-commercial purposes, provided the original author and source are credited. 
modifications leading to reduced extractability and altered affinity to the antibodies. For efficient extraction of prolamins from processed products, extraction solvents containing reducing and disaggregating agents were developed (GARCíA et al., 2005; GESSENDORFER et al., 2010; MenA et al., 2012). Matrix effects caused by different macro and micro components of foods may also change the extraction yield and immunochemical reactivity of gluten proteins through the formation of complexes or resistant aggregates (SCHERF \& PoMs, 2016; TÖRÖK et al., 2014, 2015).

The Codex Alimentarius standard (1979) states that 'the prolamin content is generally taken as $50 \%$ of gluten'. This approach is routinely used to convert the prolamin concentration measured by ELISA to gluten content. However, a recent paper demonstrated that common wheat, rye, and barley cultivars varied in this ratio, and the gluten content will be overestimated using the general conversion factor (WIESER \& KoEHLER, 2009). Many studies have focused on the diversity of the celiac-toxic protein profile of cereals, and have shown that there are differences in the immunogenic prolamin content not only among wheat, barley, and oat species but within cultivars, too (Konic-Ristic et al, 2009; Comino et al., 2011, 2012; PrANDI et al., 2012). This diversity relates to different expression patterns of storage proteins, which is primarily determined genetically, but it is also influenced by environmental factors, such as soil composition, weather, infections, heat or cold shock (Dupont \& AltenBach, 2003; WIESER et al., 2004).

Due to the lack of certified reference materials and reference methods, a comparison of the performance of the commercially available immunoanalytical tests and the identification of the factors influencing their accuracy is problematic. The development of matrices spiked with gliadin/gluten/wheat proteins is useful and suitable for raw material testing only (GENG et al., 2008; Sharma, 2012). Recently, many researchers have prepared and used incurred food samples to evaluate the factors influencing the reliability of the analytical results, such as food processing including heat treatment, etc. (Bugri et al., 2013; GOMAA \& BOYE, 2013; SHARMA et al., 2013).

The aims of this study were to characterize the protein profiles of different wheat cultivars grown in multiple harvest years and their blends by RP-HPLC and to investigate the effects of variation in protein profile among wheat flours and harvest years as a potential factor on ELISA analyses. Model matrices (cookies) incurred with wheat flours were prepared. The relative magnitude of the effects of variations in protein sources (a flour of an individual cultivar versus a flour blend), harvest years, and the processing procedure (dough forming and baking) was evaluated using two commercial ELISA kits with different target sequences.

\section{Materials and methods}

\subsection{Materials}

Grains of different wheat cultivars were provided by the Centre for Agricultural Research of the Hungarian Academy of Sciences. Cultivars Mv Magvas, Mv Mazurka, Mv Verbunkos, and Yumai-34 were harvested in three years $(2011,2012$, and 2014). Cultivar Dekan was available in only two years (2011 and 2005), samples from 2012 and 2014 were lost due to rain damage. The ingredients used in the production of the model food matrix were purchased from a local grocery store. Two sandwich ELISA kits were used: RIDASCREEN ${ }^{\circledR}$ Gliadin

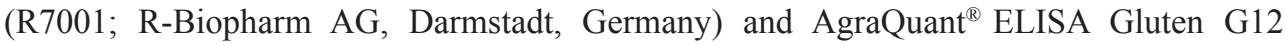


(COKAL0200; Romer Labs Ltd., Tulln, Austria). The gluten protein reference PWG-gliadin used in the RP-HPLC measurements (VAN ECKERT et al., 2006) was kindly provided by Prof. Dr. Peter Koehler, Chairman of the Working Group on Prolamin Analysis and Toxicity.

\subsection{Flour production}

Whole meals were prepared using a laboratory mill (FQC 109; Metefém, Budapest, Hungary) according to the HUNGARIAN STANDARD (1989). The bran and flour were separated by a vibratory sieve shaker (AS 200 basic; Retsch $\mathrm{GmbH}$, Haan, Germany) using a $250 \mu \mathrm{m}$ sieve for $20 \mathrm{~min}$.

Flours of individual cultivars and blends of five cultivars were prepared. Equal amounts of grains from the single cultivars were mixed before grinding to prepare the blends.

\subsection{Determination of the crude protein content of flours}

The nitrogen content of the flours was analysed by the Dumas combustion method using a TruSpec nitrogen analyzer (Leco, Moenchengladbach, Germany). The nitrogen content was multiplied by the factor of 5.7 to calculate the crude protein content (ICC STANDARD, 2000).

\subsection{Determination of the protein composition of flours by RP-HPLC}

Wheat flours $(100 \mathrm{mg})$ were extracted sequentially according to the modified Osborne procedure (WIESER et al., 1998). All suspensions were centrifuged $\left(3550 \times \mathrm{g}, 25 \mathrm{~min}, 20^{\circ} \mathrm{C}\right.$ ), the respective supernatants combined and made up to $2 \mathrm{ml}$ with the extraction solvent. The extractions were done in duplicate for each flour.

The conditions for the RP-HPLC analyses were the following: instrument, Ultimate 3000 with Chromeleon ${ }^{\circledR} 6.8$ Chromatography Data System (Dionex, Idstein, Germany); column, Acclaim ${ }^{\mathrm{TM}} 300 \mathrm{C} 18$ (particle size $3 \mu \mathrm{m}$, pore size $30 \mathrm{~nm}, 2.1 \times 150 \mathrm{~mm}$, Thermo Fisher Scientific, Braunschweig, Germany); temperature, $60^{\circ} \mathrm{C}$; injection volume, $20 \mu \mathrm{l}$ for albumins/globulins and glutenins, $10 \mu \mathrm{l}$ for gliadins; elution solvents, trifluoroacetic acid (TFA) $(0.1 \%, v / v)$ in water (A) and TFA $(0.1 \%, v / v)$ in acetonitrile (B); linear gradient, 0 min $20 \%$ B, 20 min $60 \%$ B for albumins/globulins; 0 min $24 \%$ B, 30 min $56 \%$ B for gliadins and glutenins; flow rate, $0.2 \mathrm{ml} \mathrm{min}^{-1}$; detection, $\mathrm{UV}$ absorbance at $210 \mathrm{~nm}$. The protein contents of the extracts were calculated from the absorbance areas using PWG-gliadin (VAN ECKERT et al., 2006) as calibration reference in the range of 11.6 to $46.6 \mu \mathrm{g}$.

\subsection{Model matrix production}

The incurred model product applied in this study was a cookie matrix. The recipe and procedure from our previous work were adopted (BUGYI et al., 2010, 2012). Blank cookies were prepared by mixing gluten-free flour (Dr. Schär, Mix C, 54.85\%), powdered sugar $(18.37 \%)$, salt $(0.29 \%)$, and sodium bicarbonate $(0.27 \%)$, followed by dough formation with the addition of margarine $(19.60 \%)$ and water $(6.61 \%)$ to the mixture of dry ingredients. In samples containing wheat flours, the amount of gluten-free flour was reduced and replaced with the required amount of wheat flour so that the total mass remained constant. The gliadin concentration of the cookie was set to $50 \mathrm{mg} \mathrm{kg}^{-1}$ to model the regulatory threshold level of $100 \mathrm{mg} \mathrm{kg}^{-1}$ for products with very low gluten content. Samples were taken at each major step of the matrix production: a mixture of the dry ingredients, a freeze-dried dough, and a heat-treated material (cookie) were analysed. 


\subsection{Gliadin/gluten analysis with ELISA}

Major parameters of the applied ELISA kits are summarized in Table 1. (Remark: the aim of our study was not the ranking of the kits; therefore, they were randomly coded as kit A and B.) The extraction and the assay procedures were performed in triplicates.

\begin{tabular}{lll} 
& Table 1. Main characteristics of the ELISA kits \\
\hline Parameter & $\begin{array}{l}\text { RIDASCREEN } \\
\text { Gliadin }\end{array}$ & $\begin{array}{l}\text { AgraQuant }{ }^{\mathbb{B}} \text { ELISA } \\
\text { Gluten } \mathrm{G} 12\end{array}$ \\
\hline Antibody & R5 monoclonal & G12 monoclonal \\
Target molecule & prolamin & prolamin fragment \\
Target sequence & QQPFP & QPQLPY \\
Extraction solvents & Cocktail solution and $80 \%(\mathrm{v} / \mathrm{v})$ & Extraction solution and $80 \%(\mathrm{v} / \mathrm{v})$ \\
Calibrator & ethanol & ethanol \\
Calibration curve & PWG-gliadin & Vital wheat gluten extract \\
Kit reporting unit & cubic spline & point to point \\
Conversion to gliadin unit & gliadin in $\mu \mathrm{g} \mathrm{kg}^{-1}(\mathrm{ppb})$ & gluten in $\mathrm{mg} \mathrm{kg}^{-1}(\mathrm{ppm})$ \\
\hline
\end{tabular}

\subsection{Data analysis}

Gliadin content of flours determined by the ELISA tests was normalized by the crude protein content. Gliadin recoveries (\%) in model matrices were calculated by dividing the gliadin content measured by ELISA with the nominal gliadin concentration of the sample. The nominal value was based on the amount of flour added to the model matrix and the gliadin content of flour determined by RP-HPLC. In case of the dough and cookies, the recovery values were calculated taking the observed weight loss during freeze-drying and baking into account. The weight loss was estimated by dividing the mass of the freeze-dried/baked sample by sample mass before freeze-drying/baking.

Statistical analysis was carried out by a linear Pearson correlation and analysis of variance (ANOVA) with Fisher's Least Significant Difference (LSD) post hoc test at a confidence level of 0.95 using STATISTICA 11.0 software (StatSoft Inc, Tulsa, OK, USA).

\section{Results and discussion}

\subsection{Protein composition of wheat flours}

The crude protein content and the proportion of protein fractions among wheat cultivars differed (Table 2). These parameters depend primarily on the cultivars, but the variation in harvest year was found to influence these parameters, too. These results are in agreement with a previous study (JOHANSSON et al., 2003).

Considerable differences in the relative amounts of gliadin subgroups ( $\omega 5-, \omega 1,2-, \alpha-$, and $\gamma$-gliadins) were also found among wheat cultivars (Table 2). Yearly environmental variations also influenced the gliadin composition of the cultivars, but without any obvious trend. 


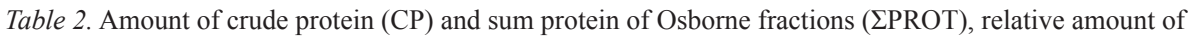
Osborne fractions (ALGL, albumins/globulins; GLUT, glutenins; PROL, prolamins) and gliadin subgroups (as \% of $\Sigma$ PROT) in wheat flours in different harvest years

\begin{tabular}{|c|c|c|c|c|c|c|c|c|c|c|}
\hline \multirow[t]{2}{*}{ Cultivar } & \multirow[t]{2}{*}{ Year } & \multicolumn{9}{|c|}{ Parameter } \\
\hline & & $\begin{array}{c}\text { CP } \\
(\mathrm{g} / 100 \mathrm{~g})\end{array}$ & $\begin{array}{c}\Sigma \text { PROT } \\
(\mathrm{g} / 100 \mathrm{~g})\end{array}$ & $\begin{array}{l}\text { ALGL } \\
(\%)\end{array}$ & $\begin{array}{c}\text { PROL } \\
(\%)\end{array}$ & $\begin{array}{c}\omega 5- \\
\text { gliadin } \\
(\%)\end{array}$ & $\begin{array}{c}\omega 1,2- \\
\text { gliadin } \\
(\%)\end{array}$ & $\begin{array}{c}\alpha \text {-gliadin } \\
(\%)\end{array}$ & $\begin{array}{c}\gamma \text {-gliadin } \\
(\%)\end{array}$ & $\begin{array}{c}\text { GLUT } \\
(\%)\end{array}$ \\
\hline \multirow[t]{3}{*}{$\begin{array}{l}\text { Mv } \\
\text { Magvas }\end{array}$} & 2011 & 10.6 & 10.2 & 11.7 & 61.4 & 3.0 & 4.5 & 29.1 & 24.8 & 26.9 \\
\hline & 2012 & 11.1 & 10.2 & 13.0 & 62.7 & 3.0 & 4.6 & 29.1 & 26.0 & 24.3 \\
\hline & 2014 & 11.0 & 10.1 & 13.7 & 59.5 & 2.7 & 4.4 & 27.3 & 25.0 & 26.8 \\
\hline \multirow[t]{3}{*}{$\begin{array}{l}\text { Mv } \\
\text { Mazurka }\end{array}$} & 2011 & 10.3 & 9.7 & 10.9 & 62.9 & 4.4 & 4.4 & 31.1 & 23.0 & 26.3 \\
\hline & 2012 & 13.9 & 13.2 & 9.1 & 64.9 & 6.2 & 5.9 & 31.6 & 21.3 & 26.0 \\
\hline & 2014 & 13.0 & 12.7 & 9.9 & 59.3 & 5.8 & 5.1 & 28.6 & 19.9 & 30.7 \\
\hline \multirow[t]{3}{*}{$\begin{array}{l}\text { Mv } \\
\text { Verbunkos }\end{array}$} & 2011 & 9.9 & 9.4 & 12.5 & 66.1 & 0.4 & 12.2 & 33.0 & 20.6 & 21.3 \\
\hline & 2012 & 12.4 & 12.2 & 10.8 & 65.3 & 0.7 & 13.7 & 33.2 & 17.6 & 24.0 \\
\hline & 2014 & 12.5 & 12.0 & 12.0 & 61.2 & 0.6 & 12.3 & 30.3 & 18.1 & 26.7 \\
\hline \multirow[t]{3}{*}{ Yumai-34 } & 2011 & 12.4 & 12.1 & 9.5 & 62.1 & 4.4 & 6.0 & 31.7 & 20.0 & 28.4 \\
\hline & 2012 & 11.6 & 10.7 & 11.5 & 61.8 & 3.7 & 5.3 & 31.3 & 21.4 & 26.7 \\
\hline & 2014 & 16.5 & 15.2 & 9.8 & 67.8 & 5.5 & 6.6 & 35.6 & 20.2 & 22.4 \\
\hline \multirow[t]{2}{*}{ Dekan } & 2011 & 9.2 & 8.5 & 16.0 & 59.8 & 2.8 & 4.9 & 29.9 & 22.3 & 24.2 \\
\hline & 2005 & 12.6 & 11.8 & 11.7 & 60.8 & 4.0 & 5.9 & 30.8 & 20.1 & 27.5 \\
\hline \multirow[t]{3}{*}{$\begin{array}{l}\text { Blended } \\
\text { flour }\end{array}$} & 2011 & 10.2 & 10.3 & 11.3 & 59.8 & 2.8 & 5.9 & 29.7 & 21.4 & 28.9 \\
\hline & 2012 & 12.0 & 11.3 & 10.7 & 64.8 & 3.8 & 7.4 & 32.0 & 21.7 & 24.4 \\
\hline & 2014 & 12.4 & 11.9 & 11.6 & 62.9 & 3.7 & 7.2 & 31.2 & 20.9 & 25.5 \\
\hline
\end{tabular}

\subsection{ELISA gliadin recovery of wheat flours}

In Table 3, the normalized ELISA responses of individual cultivars and the blended flour were compared for three harvest years. The two-factor ANOVA revealed that wheat cultivars significantly influenced the results of ELISA kits, and harvest year had no significant effect on gliadin content measured by ELISAs. The results of the ANOVA showed a significant interaction between cultivar and harvest year, indicating that the effect of cultivar is harvest year dependent. The effect of cultivar and harvest year showed a kit-dependent character. Variation between kits was probably due to their different characteristics (Table 1). It is probably due to the presence of different amounts of target epitopes in different wheat cultivars and their different changes over the harvest years. The relationship between gliadin contents measured by ELISA and protein composition of flours was studied by correlation analysis. Measured gliadin content significantly positively correlated with $\omega 1,2$ - and $\alpha$-gliadin content of flour in case of both kits. The results of ELISA kit A correlated better with $\omega 1,2-$ gliadins ( $\mathrm{r}=0.92)$ than $\alpha$-gliadin $(\mathrm{r}=0.66)$. In case of kit $\mathrm{B}$, the correlation coefficients were similar for these parameters ( 0.60 and 0.63 , respectively). 
Table 3. Normalized gliadin content as measured with ELISA kit A and ELISA kit B in wheat flours in different harvest years

\begin{tabular}{|c|c|c|c|}
\hline \multirow[t]{2}{*}{ Cultivar } & \multirow[t]{2}{*}{ Year } & \multicolumn{2}{|c|}{ Normalized gliadin content $(\mathrm{g} / 100 \mathrm{~g})$} \\
\hline & & ELISA kit A & ELISA kit B \\
\hline \multirow[t]{3}{*}{ Mv Magvas } & 2011 & $5.9^{b}$ & $4.3^{\mathrm{cd}}$ \\
\hline & 2012 & $5.6^{\mathrm{ab}}$ & $3.1^{\mathrm{ab}}$ \\
\hline & 2014 & $4.7^{\mathrm{a}}$ & $2.6^{\mathrm{a}}$ \\
\hline \multirow[t]{3}{*}{ Mv Mazurka } & 2011 & $5.0^{\mathrm{a}}$ & $3.1^{\mathrm{ab}}$ \\
\hline & 2012 & $6.3^{\mathrm{bc}}$ & $3.3^{\mathrm{ab}}$ \\
\hline & 2014 & $4.8^{\mathrm{a}}$ & $3.7^{\mathrm{bc}}$ \\
\hline \multirow{3}{*}{ Mv Verbunkos } & 2011 & $13.0^{\mathrm{i}}$ & $6.1^{\text {gh }}$ \\
\hline & 2012 & $15.1^{\mathrm{j}}$ & $6.4^{\mathrm{hi}}$ \\
\hline & 2014 & $11.5^{\mathrm{h}}$ & $6.2^{\text {ghi }}$ \\
\hline \multirow[t]{3}{*}{ Yumai-34 } & 2011 & $9.5^{\mathrm{g}}$ & $7.0^{\mathrm{i}}$ \\
\hline & 2012 & $7.3^{\mathrm{de}}$ & $5.4^{\mathrm{efg}}$ \\
\hline & 2014 & $9.7^{\mathrm{g}}$ & $6.2^{\text {ghi }}$ \\
\hline \multirow[t]{2}{*}{ Dekan } & 2011 & $7.0^{\mathrm{cd}}$ & $5.5^{\text {efg }}$ \\
\hline & 2005 & $8.9^{\mathrm{fg}}$ & $6.0^{\mathrm{fgh}}$ \\
\hline \multirow[t]{3}{*}{ Blended flour } & 2011 & $7.3^{\mathrm{de}}$ & $4.3^{\mathrm{cd}}$ \\
\hline & 2012 & $8.1^{\mathrm{ef}}$ & $4.8^{\mathrm{de}}$ \\
\hline & 2014 & $7.8^{\mathrm{de}}$ & $5.1^{\text {def }}$ \\
\hline
\end{tabular}

Mean values marked with different letters are significantly different within each column at 0.05 probability level (Fisher LSD).

\subsection{ELISA gliadin recovery of model matrices incurred with wheat flours}

An individual cultivar with a relatively constant protein composition across the years (cultivar Mv Magvas) and flour blends were used to prepare incurred matrices. The effects of varying protein composition of the flours and the processing procedure (dough forming and baking) on gliadin recoveries were evaluated for three harvest years using two different ELISA tests (Table 4). In most cases the applied kits showed significantly higher gliadin recovery when using the blended flour made of five cultivars as protein source compared to the flours of individual cultivars (Mv Magvas). The gliadin recoveries for flour from the same cultivar varied with the harvest year, but the ANOVA showed that harvest year had no significant effect on recovery values. The ANOVA also revealed significant interactions among ELISA kit, protein source, and harvest year in accordance with the observed results in section 2.2. Gliadin recoveries are also dependent on processing. Means were not statistically different between powder mixture and dough samples; protein hydration and dough formation did not significantly affect the recoveries. However, in cookies considerably different values were observed compared to dough samples in a kit-dependent manner. The experienced deviation of the gliadin contents could be due to an inefficient extraction method or any modifications influencing changes in antibody-antigen binding (Bugy et al., 2013; Sharma et al., 2013; TÖRÖK et al., 2015). The effect of protein source and harvest year on gliadin recoveries is dependent on the level of processing factor according to ANOVA results. 
Table 4. Gliadin recovery of samples incurred with different flours (flour of individual cultivar Mv Magvas or blended flour) determined by ELISA kit A and ELISA kit B

\begin{tabular}{|c|c|c|c|c|c|}
\hline \multirow[t]{2}{*}{ ELISA kit } & \multirow[t]{2}{*}{ Wheat flour } & \multirow[t]{2}{*}{ Level of processing } & \multicolumn{3}{|c|}{ Harvest year } \\
\hline & & & 2011 & 2012 & 2014 \\
\hline \multirow[t]{6}{*}{ A } & Mv Magvas & Powder mixture & $91.2^{\text {defgh }}$ & $77.9^{\text {bcde }}$ & $73.0^{\mathrm{bcd}}$ \\
\hline & & Dough & $79.7^{\text {bcdef }}$ & $68.5^{\text {abcd }}$ & $79.6^{\text {bcdef }}$ \\
\hline & & Cookie & $63.3^{\mathrm{ab}}$ & $49.1^{\mathrm{a}}$ & $72.9^{\mathrm{bcd}}$ \\
\hline & Blended flour & Powder mixture & $110.1^{\text {hijk }}$ & $116.8^{\mathrm{ijk}}$ & $152.0^{\mathrm{m}}$ \\
\hline & & Dough & $104.4^{\text {ghijk }}$ & $102.9^{\text {ghijk }}$ & $153.2^{\mathrm{m}}$ \\
\hline & & Cookie & $85.9^{\text {bcdefg }}$ & $87.7^{\text {cdefgh }}$ & $101.1^{\text {fghijk }}$ \\
\hline \multirow[t]{6}{*}{ B } & Mv Magvas & Powder mixture & $72.8^{\text {bcd }}$ & $105.8^{\mathrm{ghijk}}$ & $88.7^{\text {defgh }}$ \\
\hline & & Dough & $63.5^{\mathrm{ab}}$ & $121.6^{\mathrm{jk}}$ & $86.6^{\text {cdefg }}$ \\
\hline & & Cookie & $65.1^{\mathrm{abc}}$ & $108.0^{\text {ghijk }}$ & $98.3^{\text {efghi }}$ \\
\hline & Blended flour & Powder mixture & $99.2^{\text {efghij }}$ & $162.5^{\mathrm{m}}$ & $145.0^{\mathrm{lm}}$ \\
\hline & & Dough & $98.6^{\text {efghi }}$ & $159.0^{\mathrm{m}}$ & $123.9^{\mathrm{kl}}$ \\
\hline & & Cookie & $89.2^{\text {defgh }}$ & $192.9^{\mathrm{n}}$ & $116.8^{\mathrm{ijk}}$ \\
\hline
\end{tabular}

Mean values marked with different letters are significantly different at a 0.05 probability level (Fisher LSD).

The experimental design applied in our study not only allowed to investigate these factors, but also to calculate their contribution to the overall uncertainty of the measurements. It may be of interest to find out how much of the variance in the experiment might be attributed to the difference in protein sources, to the processing procedure, to the choice of ELISA test, and to random deviation among replicates. The results of the ANOVA showed that $48 \%$ of the total variance was attributed to the differences among protein sources, while harvest year $(11 \%)$, the applied assay $(9 \%)$, and the processing procedure $(2 \%)$ had minor contributions to total variance in this experiment.

\section{Conclusions}

This study demonstrated the effects of different wheat cultivars, harvest years, food processing procedures (dough forming, heat treatment), and applied ELISA kits on the reliability of the analytical results. Protein source (different wheat cultivars) was the most important factor and was statistically significant. The results cannot be generalised, but they draw attention to the importance of the improvement of ELISA methods and the development of a wellcharacterized incurred reference material for gluten analysis. Our experimental design can be extended with other methods and further cultivars, and allows the investigation and identification of the criteria for the selection of source materials for the production of suitable reference materials for the analysis of gluten.

This research is related to the scientific goals of the MoniQA Association and the national project ÚMFT TÁMOP4.2.1/B-09/1/KMR-2010-0002. 


\section{References}

BugYi, Z., NAgY, J., TÖRÖK, K., HAJAS, L. \& TÖмÖsKÖZI S. (2010): Towards development of incurred materials for quality assurance purposes in the analysis of food allergens. Anal. Chim. Acta, 672, 25-29.

Bugyi, Z., Török, K., Hajas, L., Adonyi, Z., Diaz-Amigo, C., Popping, B., Poms, R., Kerbach, S. \& TömösköZi, S. (2012): Development of incurred reference material for improving conditions of gluten quantification. $J$. AOAC Int., 95, 382-387.

Bugyi, Z., TöröK, K., Hajas, L., Adonyi, Z., Popping, B. \& TömösköZI, S. (2013): Comparative study of commercially available gluten ELISA kits using an incurred reference material. Qual. Assur. Saf. Crop., 5, 79-87.

Codex Alimentarius (1979): Codex standard for foods for special dietary use for persons intolerant to gluten. Codex Alimentarius Commission, Rome, Italy, STAN 118-1979, revised: 2008, amendment: 2015, 3 pages.

Comino, I., Real, A., de Lorenzo. L., Cornell, H., López-Casado, M.Á., Barro, F., Lorite, P., Torres, M.I., Cebolla, Á. \& Sousa, C. (2011): Diversity in oat potential immunogenicity: basis for the selection of oat varieties with no toxicity in celiac disease. Gut, 60, 915-922.

Comino, I., Real, A., Gil-Humanes, J., Pistón, F., de Lorenzo, L., Moreno, M.D.L., López-Casado, M.Á., Lorite, P., Cebolla, Á., Torres, M.I., Barro, F. \& Sousa, C. (2012): Significant differences in coeliac immunotoxicity of barley varieties. Mol. Nutr. Food Res., 56, 1697-1707.

Commission of the EuRopean Communities (2009): Commission Regulation (EC) No 41/2009 of 20 January 2009 concerning the composition and labelling of foodstuffs suitable for people intolerant to gluten. OJ. L. 186, 16, 35 .

Diaz-Amigo, C. \& Popping, B. (2012): Gluten and gluten-free: issues and considerations of labeling regulations, detection methods, and assay validation. J. AOAC Int., 95, 337-349.

Diaz-Amigo, C. \& Popping, B. (2013): Accuracy of ELISA detection methods for gluten and reference materials: a realistic assessment. J. Agr. Food Chem., 61, 5681-5688.

Dupont, F.M. \& Altenbach, S.B. (2003): Molecular and biochemical impacts of environmental factors on wheat grain development and protein synthesis. J. Cereal Sci., 38, 133-146.

García, E., Llorente, M., Hernando, A., Kieffer, R., Wieser, H. \& Méndez, E. (2005): Development of a general procedure for complete extraction of gliadins for heat processed and unheated foods. Eur. J. Gastroen.. Hepat., $17,529-539$.

Geng, T., Westphal, C.D. \& Yeung, J.M. (2008): Detection of gluten by commercial test kits: effects of food matrices and extraction procedures. -in: Siantar, D.P., Trucksess, M.W., Scott, P.M. \& Herman, E.M. (Eds) Food contaminants. ACS Symposium Series 1001, pp. 462-475.

Gessendorfer, B., Wieser, H. \& Koehler, P. (2010): Optimisation of a solvent for the complete extraction of prolamins from heated foods. J. Cereal Sci., 52, 331-332.

GomAA, A. \& Boye, J.I. (2013): Impact of thermal processing time and cookie size on the detection of casein, egg, gluten and soy allergens in food. Food Res. Int., 52, 483-489.

HungaRIAN STANDARD (1989): Élelmezési, takarmányozási, ipari magvak és hántolt termények vizsgálata. A búzaliszt laboratóriumi elöállitása (Edible, fodder and industrial seeds and husked products. Quality tests. Production of wheat flour in laboratory). Hungarian Standard Institution, Budapest, Hungary, MSZ 6367-9:1989, 4 pages.

ICC STANDARD (2000): Determination of crude protein in grain and grain products for food and feed by the Dumas combustion principle. International Association for Cereal Science and Technology, Vienna, Austria. No. 167.

Johansson, E., Prieto-Linde, M.L., Svensson, G., \& Jönsson, J.Ö. (2003): Influences of cultivar, cultivation year and fertilizer rate on amount of protein groups and amount and size distribution of mono- and polymeric proteins in wheat. J. Agr. Sci., 140, 275-284.

Koehler, P., Wieser, H. \& Scherf, K.A. (2016): Celiac disease. -in: Wrigley, C.W., Corke, H., Seetharaman, K. \& Faubion, J. (Eds) Encyclopedia of food grains, $2^{\text {nd }}$ ed., Vol. 2: Nutrition and food grains. Academic Press, Elsevier, Oxford, Waltham, pp. 83-90.

Konic-Ristic, A., Dodig, D., Krstic, R., Jelic, S., Stankovic, I., Ninkovic, A., Radic, J., Besu, I., Bonaci-Nikolic, B., Jojic, N., DJorDJevic, M., Popovic, D. \& Juranic, Z. (2009): Different levels of humoral immunoreactivity to different wheat cultivars gliadin are present in patients with celiac disease and in patients with multiple myeloma. BMC Immunol., 10, 32.

Mena, M.C., Lombardía, M., Hernando, A., Méndez, E. \& Albar, J.P. (2012): Comprehensive analysis of gluten in processed foods using a new extraction method and a competitive ELISA based on the R5 antibody. Talanta, $91,33-40$ 
Prandi, B., Bencivenni, M., Faccini, A., Tedeschi, T., Dossena, A., Marchelli, R., Galaverna, G. \& Sforza, S. (2012): Composition of peptide mixtures derived from simulated gastrointestinal digestion of prolamins from different wheat varieties. J. Cereal Sci., 56, 223-231.

Sabatino, A., Biagi, F., Giuffrida, P. \& Corazza, G.R. (2013): The spectrum of gluten-related disorders. Curr. Pediatr. Rep., 1, 182-188.

Scherf, K.A. \& Poms, R.E. (2016): Recent developments in analytical methods for tracing gluten. J. Cereal Sci., 67, $112-122$.

Scherf, K.A., Koehler, P. \& Wieser, H. (2016): Gluten and wheat sensitivities - an overview. J. Cereal Sci., 67, $2-11$.

Sharma, G.M. (2012): Immunoreactivity and detection of wheat proteins by commercial ELISA kits. J. AOAC Int., $95,364-371$.

Sharma, G.M., Khuda, S.E., Pereira, M., Slate, A., Jackson, L.S., Pardo, C., Williams, K.M. \& Whitaker, T.B. (2013): Development of an incurred cornbread model for gluten detection by immunoassays. J. Agr. Food Chem., 61, 12146-12154.

TöröK, K., Horváth, V., Horváth, Á., Hajas, L., Bugyi, Z. \& Tömösközi, S. (2014): Investigation of incurred singleand multi-component model food matrices for determination of food proteins triggering allergy and coeliac disease. Eur. Food Res. Technol., 239, 923-932.

TöröK, K., Hajas, L., Bugyi, Z., BalÁzs, G. \& TöмÖsкÖZI, S. (2015): Investigation of the effects of food processing and matrix components on the analytical results of ELISA using an incurred gliadin reference material candidate. Acta Alimentaria, 44, 390-399.

van Eckert, R., Berghofer, E., Ciclitira, P.J., Chirdo, F., Denery-Papini. S., Ellis, H.J., Ferranti, P., Goodwin, P., Immer, U., Mamone, G., Méndez, E., Mothes, T., Novalin, S., Osman, A., Rumbo, M., Stern, M., Thorell, L., Whim, A. \& WiESER, H. (2006): Towards a new gliadin reference material isolation and characterisation. J. Cereal Sci., 43, 331-341.

Wieser, H., Antes, S. \& SEILmeIER, W. (1998): Quantitative determination of gluten protein types in wheat flour by reversed-phase high-performance liquid chromatography. Cereal Chem., 75, 644-650.

Wieser, H., Gutser, R. \& von Tucher, S. (2004): Influence of sulphur fertilisation on quantities and proportions of gluten protein types in wheat flour. J. Cereal Sci., 40, 239-244.

Wieser, H. \& Koehler, P. (2009): Is the calculation of the gluten content by multiplying the prolamin content by a factor of 2 valid? Eur. Food Res. Technol., 229, 9-13. 